\title{
Sintesis $N$-Oktilsinamamid dan Aktivitasnya terhadap Sitotoksik Sel Kanker Leukemia P388
}

\section{Synthesis $N$-Octylcinnamamide and Cytotoxicity Activity against P388 Leukemia Cancer Cells}

\author{
Teni Ernawati ${ }^{1}$, Neneng Nurhalimah ${ }^{2}, \operatorname{Minarti}^{1}$ \\ ${ }^{1}$ Pusat Penelitian Kimia-Lembaga Ilmu Pengetahuan Indonesia (LIPI), Kawasan Puspiptek Serpong 15314 \\ Tangerang Selatan \\ ${ }^{2}$ Program Studi Farmasi-Fakultas Kedokteran dan Ilmu Kesehatan, UIN Syarif Hidayatulah Jakarta
}

Email: teni.ernawati001@gmail.com

Received: August 2017; Revised: November 2017; Accepted: November 2017; Available Online: November 2017

\begin{abstract}
Abstrak
Sintesis senyawa $\mathrm{N}$-Oktilsinnamamid yang diturunkan dari senyawa metil trans-sinamat dengan menggunakan katalis basa telah dilakukan. Senyawa metil sinamat terlebih dahulu dikonversi menjadi asam sinamat melalui reaksi hidrolisis dengan basa menghasilkan asam sinamat. Selanjutnya asam sinamat diamidasi dengan menggunakan oktilamin dan 1,3 disikloheksilkarboodiimide (DCC) dan 4dimetilaminopiridin (DMAP) sebagai katalis. Dari penelitian ini diperoleh rendemen hasil sintesis asam sinamat, sintesis $N$-Oktilsinnamami yang cukup baik. Hasil reaksi diidentifikasi dengan menggunakan ${ }^{1} \mathrm{H}-\mathrm{NMR},{ }^{13} \mathrm{C}$-NMR dan LC-MS. Uji sitotoksik senyawa $N$-Oktilsinamamid terhadap sel leukemia P388 diperoleh nilai $\mathrm{IC}_{50}=6.71 \mu \mathrm{g} / \mathrm{mL}$.
\end{abstract}

Kata kunci : $N$-oktilsinnamamid, metil sinamat, amidasi, asam sinamat, sel kanker P388

\begin{abstract}
Synthesis of $\mathrm{N}$-Octylcinnamamide compound derived from methyl trans-cinnamate using abase catalyst has been done. First, The compound of methyl trans-cinnamate was converted into cinnamic acid by hydrolysis reaction with an alkaline condition. Furthermore cinnamic acid was amidated by using octylamine and 1.3 dicyclohexylcarbodiimide (DCC) and 4-dimethylaminopyridine (DMAP) as a catalyst. The results of this study were obtained synthesis of cinnamic and synthesis of $\mathrm{N}$ Octylcinnamamide are good enough. Identification of this product was using by ${ }^{1} \mathrm{H}-\mathrm{NMR},{ }^{13} \mathrm{C}-\mathrm{NMR}$ and LC-MS. Cytotoxic test of $N$-Octylcinnamamide against P388 leukemia cells was obtained $\mathrm{IC}_{50}=$ $6.71 \mu \mathrm{g} / \mathrm{mL}$.
\end{abstract}

Keywords: N-Octylcinnamamide, methyl cinnamate, cinnamic acid, cancer cells, P388.

DOI: http://dx.doi.org/10.15408/jkv.v3i2.5843

\section{PENDAHULUAN}

Penyakit kanker telah menjadi salah satu penyebab kematian utama di Indonesia.Saat ini kanker tidak hanya menyerang orang dewasa, tetapi juga banyak menimpa anak-anak. Menurut Data Rumah Sakit Kanker Darmais (RSKD) tahun 2012, jumlah kasus baru kanker anak mencapai lebih dari 11.000 pasien per tahun di seluruh Indonesia. Data Badan 
Kesehatan Dunia (WHO) menyebutkan bahwa tahun 2003, setiap tahun timbul lebih dari 10 juta kasus penderita baru kanker dengan prediksi peningkatan setiap tahun kurang lebih 20\% (De et al., 2011). Jumlah penderita baru penyakit kanker tahun 2020 diperkirakan meningkat hampir 20 juta penderita. Banyak upaya yang dilakukan untuk pengobatan kanker antara lain dengan menggunakan obatobatan, baik natural maupun sintetik. Alternatif pengobatan kanker lainnya adalah dengan melakukan kemoterapi, penyinaran, pembedahan, dan terapi kombinasi. Akan tetapi, masing-masing cara dari pengobatan kanker tersebut masih memiliki kelemahan, sehingga pengobatan kanker pada umumnya sampai saat ini belum ada yang menunjukkan hasil yang memuaskan. Untuk itu, peluang untuk mencari senyawa bioaktif dari bahan alam ataupun mensintesis senyawa sejenis dengan bahan alam untuk pengobatan kanker masih sangat besar (Humpries et al., 1986; Hayakawa et al., 2004; Dykes dan Waud, 1995). Penyakit kanker telah menjadi salah satu penyebab kematian utama di Indonesia.

Indonesia dikenal mempunyai potensi sumber daya alam nya yang kaya, baik itu biota darat maupun biota laut. Tanaman yang tumbuh di Indonesia sangat banyak dan beragam, mulai dari tanaman pangan sampai ke tanaman obat. Banyak potensi tanaman obat yang ada di Indonesia, salah satunya adalah lengkuas dari spesies Alpinia malaccensis. Lengkuas jenis ladja goa ini memiliki kandungan minyak atsiri yang dominan. Komponen minyak atsiri yang paling besar dari ladja goa adalah metil sinamat. Beberapa tanaman lain yang memiliki kandungan metil sinamat adalah Conocephalum conicum, Narcissus jonquilla L, Gastrochilus panduratum Ridl (Bhatia et al., 2007; Muchtaridi et al., 2008). Di Pusat Penelitian Kimia LIPI, metil sinamat telah berhasil diisolasi secara skala pilot dengan rendemen yang cukup baik sekitar 55\% dan kemurnian produk yang tinggi, 99\% (Ernawati dan Fairusi, 2013). Oleh karena nya potensi hasil alam yang besar itu dimanfaatkan untuk penelitian dan pengembangan bahan baku obat dengan menggunakan bahan dasar dari alam Indonesia, khususnya dari bahan dasar metil sinamat (Ernawati et al., 2013). Penelitian di bidang organik sintesis terhadap derivat metil sinamat juga telah berkembang. Asam sinamat merupakan analog dari metil sinamat, yang termasuk dalam jalur turunan asam shikimat (De et al., 2011). Asam sinamat dan analog alaminya dikenal sebagai pengobatan kanker selama beberapa abad. Banyak senyawa sinamamido baik itu yang diperoleh secara alami maupun sintetik dievaluasi kemampuannya terhadap sel kanker. Salah satu senyawa sinamamid yang diisolasi dari fermentasi Streptomyces griseoluteus, yaitu senyawa 2-Metil sinamid memperlihatkan antiinvasiv atau efek antimetastatik yang signifikan. Pretreatmen terhadap maglinan melanoma sel C8161 dan A375M secara in vitro menghasilkan nilai $\mathrm{IC}_{50}$ sebesar 12.5 $\mu \mathrm{g} / \mathrm{mL}$. Sinamik nitrogen mustard senyawa turunan dari distamycin A yang merupakan vinil analog dari tallimustine $\mathrm{A}$, memperlihatkan aktivitas antileukemia yang sangat baik dan secara signifikan lebih unggul dari tallimustine (De et al., 2011). Keberadaan gugus amidin karena sifat basa yang kuat, diharapkan dapat benar benar terprotonasi dalam kondisi biologis dan mungkin berpengaruh dalam memainkan kunci baik dalam ikatan DNA dan sel atau jaringan bioavibilitas. Penggantian gugus amidin dengan amidin dasar atau yg bukan akan menyebabkan peningkatan sitotoksisitas dalam beberapa kasus, seperti halnya senyawa turunan asam sinamat mustard bisa 20 kali lipat dari senyawa asalnya (Allen et al., 2011; Bahrami et al., 2013; Lanigan et al., 2013). Di sini, kami fokus untuk mensintesis senyawa $N$ oktil sinnamamid dan evaluasi aktivitas sitotoksisitasnya terhadap penghambatan sel leukemia P388.

\section{METODE PENELITIAN}

\section{Alat dan Bahan}

Peralatan yang digunakan dalam penelitian ini adalah labu bulat, kolom kromatografi, temometer, hot plate dan stirer, rotary evaporator, penangas minyak, lampu UV, pipet eppendorf, spektrofotometer UVVis, dan spektrometer ${ }^{1} \mathrm{H}-\mathrm{NMR}(500 \mathrm{MHz})$ dan ${ }^{13} \mathrm{C}$-NMR (125 MHz) JEOL, LC-MS, serta peralatan gelas kimia lainnya.

Bahan-bahan yang digunakan dalam penelitian ini adalah senyawa metil sinamat hasil isolasi dari minyak lengkuas ( $A$. malaccensis), natrium hidroksida $(\mathrm{NaOH}-$ E.Merck), oktilamin (E.Merck) 1,3 dicyclohexylcarbodiimide (DCC) (SigmaAldrich), 4-dimethylaminopyridine (DMAP) 
(Sigma-Aldrich), pelarut organik (metanol, etanol, butanol, etil asetat, diklorometan, dan n-heksana), asam klorida $(\mathrm{HCl})$, natrium sulfat anhidrat $\left(\mathrm{Na}_{2} \mathrm{SO}_{4}\right)$, aquades, air laut, udang Artemia salina Leach, dimetil sulfoksida (DMSO), kertas saring, silika gel, dan plat kromatografi lapisan tipis (KLT) $\mathrm{GF}_{254}$.

\section{Hidrolisis Metil Sinamat}

Dalam Erlenmeyer $1 \mathrm{~L}$ dibuat larutan $\mathrm{NaOH}$ dengan menimbang $\mathrm{NaOH}$ sebanyak $36.9 \mathrm{~g}(0.92 \mathrm{~mol})$ dalam $600 \mathrm{~mL}$ etanol $95 \%$. Setelah seluruh $\mathrm{NaOH}$ larut sempurna, dimasukkan metil sinamat sebanyak $50 \mathrm{~g}$ (308 mmol) sedikit demi sedikit. Campuran reaksi diputar dengan menggunakan magnetik stirrer pada suhu kamar sampai reaksi sempurna. Pengecekan reaksi dilakukan dengan plat KLT. Reaksi sempurna setelah 4 jam, kemudian reaksi difiltrasi dan residu yang terbentuk dicuci dengan akuades untuk menghilangkan garam yang terbentuk. Sedangkan filtrat dinetralkan dengan penambhan $\mathrm{HCl}$ hingga terbentuk endapan dan dilakukan filtrasi kembali.Produk padatan yang berupa asam sinamat kemudian dikeringkan dalam oven sekitar suhu $50{ }^{\circ} \mathrm{C}$. Rendemen produk asam sinamat yang diperoleh dari proses hidrolisis ini sebesar $85 \%$ (38.75 g, $262 \mathrm{mmol})$

\section{Amidasi Asam Sinamat}

Sebanyak 2 gram asam sinamat $(13.50$ mmol) dimasukkan ke dalam labu reaksi 100 $\mathrm{mL}$, kemuduan ditambahkan $2.7 \mathrm{~mL}$ oktil amin (16.2 mmol), $2.23 \mathrm{~g}$ DCC (10.8 mmol) dan 1.32 g DMAP. Campuran reaksi di reaksikan di atas oil bath dengan suhu $60{ }^{\circ} \mathrm{C}$ dan diaduk dengan menggunakan magnetik stirrer. Reaksi berlangsung selama 5 jam dan produk dimurnikan dengan menggunakan kolom kromatografi. Rendemen produk yang diperoleh sebesar $53.65 \% \quad(1.875 \mathrm{~g}, \quad 7.24$ mmol)

\section{Uji Sitotoksisitas dengan Metode MTT}

$\begin{array}{crcr}\text { Senyawa uji } & \text { dibuat larutan stok } \\ \text { sebanyak } & 1000 & \text { ppm dengan }\end{array}$ dimetilsulfoksida.Larutan stok kemudian diencerkan dengan media Dulbecco's Modified Eagle Media (DMEM) untuk uji terhadap sel LeukemiaP388 sehingga diperoleh variasi konsentrasi larutan uji. Konsentrasi larutan uji yang digunakan adalah 100, 50, dan $10 \mathrm{ppm}$. Sel ditumbuhkan dalam media DMEM dan didistribusikan ke dalam 96 well plate dengan jumlah 2000 sel/well $(100 \mu \mathrm{l})$ kemudian diinkubasi selama 24 jam pada suhu $37{ }^{\circ} \mathrm{C}$ dalam inkubator $\mathrm{CO}_{2} 5 \%$. Larutan uji dalam berbagai variasi konsentrasi masing-masing ditambahkan ke dalam sel HeLa, dan diinkubasi kembali selama 24 jam. Setiap senyawa uji dilakukan pengujian sebanyak tiga kali pengulangan. 3-(4,5-dimetiltiazol-2-il(2,5-difenil tetrazolium bromida) (MTT) dalam natrium hidrogen karbonat $\left(\mathrm{NaHCO}_{3}\right)$ kemudian ditambahkan $10 \mu \mathrm{l} /$ well pada tiap konsentrasi dan diinkubasi lebih lanjut selama 4 jam pada suhu $37^{\circ} \mathrm{C}$ sampai terbentuk formazan(Cozzi et al., 2003; Wu et al., 2008). Sel yang hidup akan mengkonversikan MTT menjadi formazan yang berwarna biru tua. Formazan yang terbentuk dilarutkan dalam etanol 96\%. Serapan dibaca dengan ELISA reader pada panjang gelombang $562 \mathrm{~nm}$. Persentase penghambatan proliferasi dihitung berdasarkan nilai Optical Density (OD) dengan rumus:

$$
\% \text { inhibisi }=\frac{(\text { OD kontrol-OD sampel })}{(\text { OD kontrol })} \times 100 \%
$$

Hasil dari \% inhibisi kemudian diplotkan dengan konsentrasi atau log konsentrasi dan diperoleh persamaan regresi linier. Harga viabilitas sel $50 \%$ dimasukkan dalam persamaan regresi linier yang diperoleh sehingga diperoleh nilai $\mathrm{IC}_{50}$.

\section{HASIL DAN PEMBAHASAN}

Dalam penelitian ini kita menggunakan raw material senyawa metil sinamat hasil isolasi dari Alpinia malaccensis.Sintesis diawali dengan reaksi hidrolisis, kemudian dilanjutkan dengan reaksi amidasi. Proses reaksi amidasi dilakukan dengan menggunakan amidation agent berupa oktilamin (16.2 mmol) serta katalis DCC dan DMAP masing-masing sebanyak $10.8 \mathrm{mmol}$. Pada reaksi modifikasi yang dilakukan, senyawa DCC berfungsi sebagai aktifator gugus karboksilat dimana gugus tersebut selanjutnya menjadi suatu agen pengasilasi yang reaktif. Sementara DMAP merupakan senyawa yang memiliki efek katalitik yang kuat dan digunakan sebagai katalis nukleofilik. Gugus dimetil amino pada DMAP berfungsi sebagai subtituen donor elektron dan memperbesar efek nukleofilitas. Penggunaan aktifator DCC dalam reaksi amidasi ini 
menyebabkan terbentuknya senyawa DCU (n,n'-dicyclohexylurea) sebagai produk samping dari reaksi tersebut. Reaksi berlangsung selama 5 jam dalam suhu refluks $60^{\circ} \mathrm{C}$ dengan hasil reaksi (crued) berupa padatan berwarna kuning cerah. Identifikasi awal secara kualitatif dilakukan dengan Kromatografi Lapis Tipis (KLT) dengan fase gerak n-heksan dan etil asetat 3:1. Dari hasil tersebut terlihat 3 spot yang berbeda masingmasing merupakan senyawa produk oktil sinamamide dan DCU sebagai side product. Produk kemudian dimurnikan dengan menggunakan kolom kromatografi. Elusidasi produk dilakukan dengan menggunakan UV, FTIR, LCMS, ${ }^{1} \mathrm{H}-\mathrm{NMR}$ dan ${ }^{13} \mathrm{C}-\mathrm{NMR}$.

Hasil analisis spektrofotometer UV senyawa oktilsinamamid memiliki serapan di daerah panjang gelombang 250-300 nm. Data FTIR menunjukkan bahwa senyawa nitro oktilsinamamid memiliki gugus fungsional gugus N-H ditunjukkan pada $v 3300 \mathrm{~cm}^{-1}$. Gugus fungsional amida $(\mathrm{N}-\mathrm{C}=\mathrm{O})$ ditunjukkan dengan adanya pita pada bilangan gelombang $v 1625 \mathrm{~cm}^{-1}$. Serapan pita C-H pada gugus aromatik ditunjukkan pada $\vee 3055 \mathrm{~cm}^{-1}$. Untuk kelompok aromatik, $\mathrm{C}=\mathrm{C}$ aril ditunjukkan pada bilangan gelombang $1336 \mathrm{~cm}^{-1}$. Serapan pita $\mathrm{N}-\mathrm{O}$ pada gugus aromatik ditunjukkan pada $v$ $1336 \mathrm{~cm}^{-1}$.

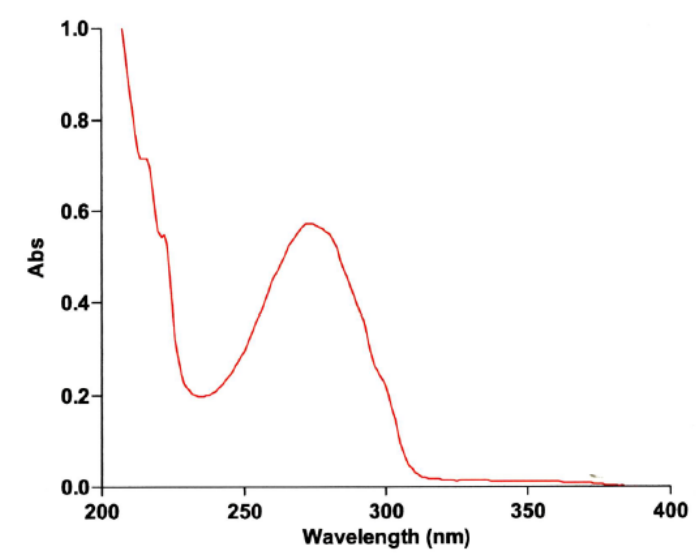

Gambar 1. Spektrum UV senyawa oktilsinamamid

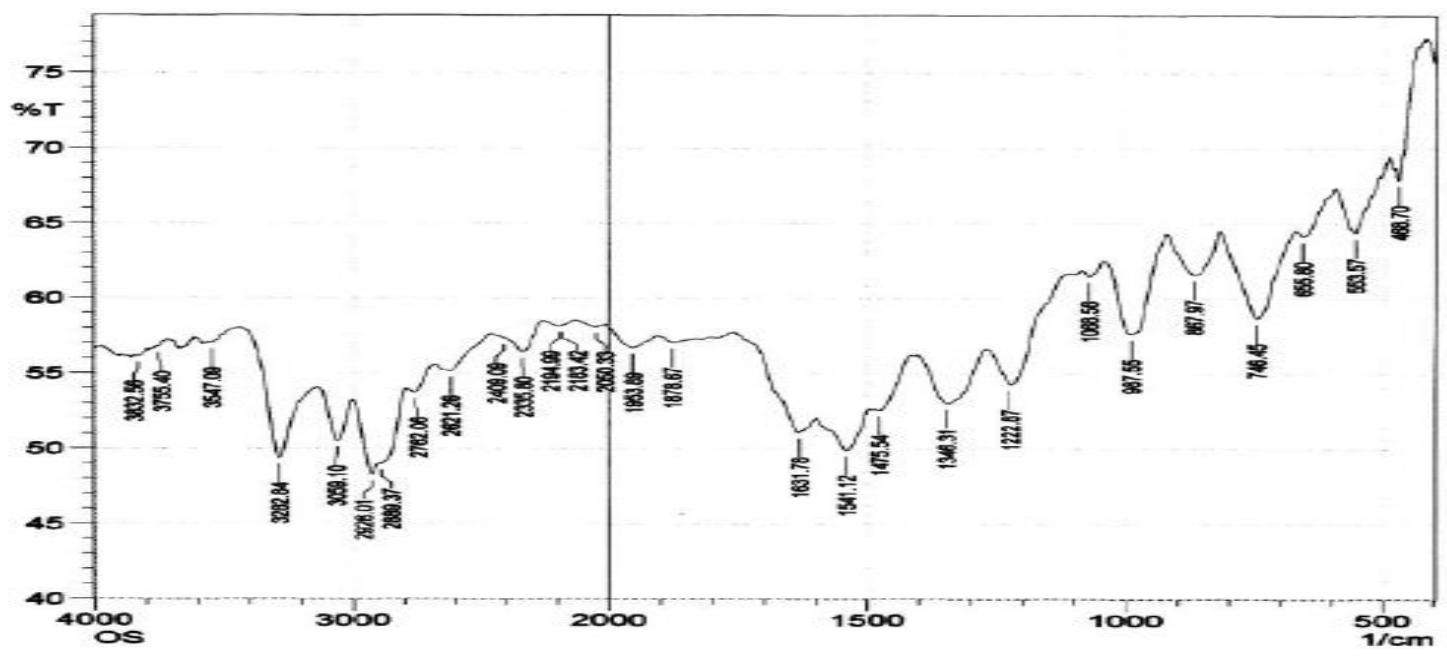

Gambar 2. Spektrum FTIR senyawa oktilsinamamid

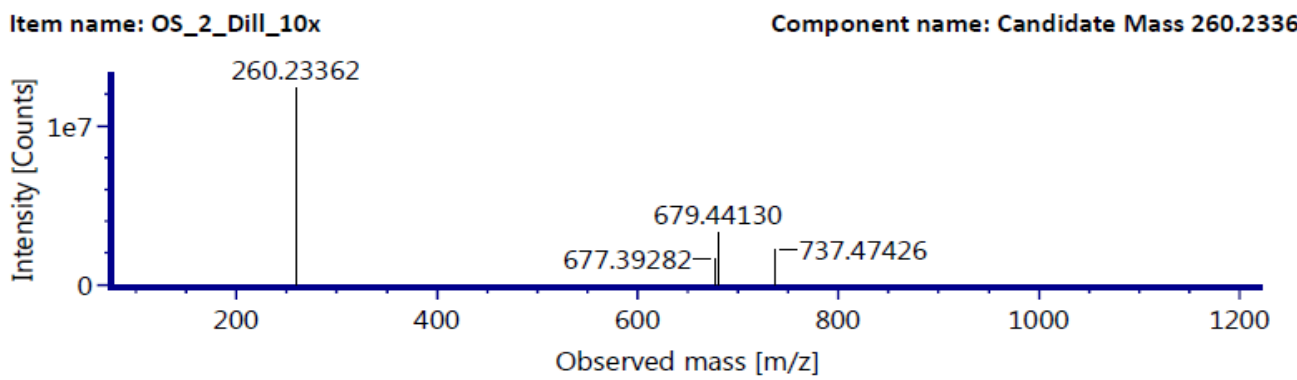

Gambar 3. Spektrum LCMS senyawa oktilsinamamid 
Data pengukuran LCMS untuk senyawa nitro oktilsinamamid diperoleh $\quad[\mathrm{M}+\mathrm{H}]^{+}=$ 260.23362, artinya senyawa itu memiliki berat molekul sebesar $[\mathrm{M}]^{+}=259.23362$. Dari hasil analisa maka dapat diasumsikan bahwa rumus molekul senyawa ini adalah $\mathrm{C}_{17} \mathrm{H}_{25} \mathrm{NO}$ (n-oktil sinamamid). Penentuan asumsi ini hasil analisa dari ${ }^{1} \mathrm{H}-\mathrm{NMR}$ dan ${ }^{13} \mathrm{C}-\mathrm{NMR}$ serta didukung pada hasil LC-MS yang memperlihatkan puncak ion molekular $[\mathrm{M}+\mathrm{H}]+=260.23362$. Dari data tersebut dapat diketahui bahwa senyawa oktil sinamamid ini memiliki massa molekul relatif 259.23362. Perolehan massa molekul relatif yang ganjil juga dapat memperkuat asumsi bahwa dalam senyawa ini hanya terdapat satu atom $\mathrm{N}$.

Hasil karakterisasi senyawa nitro oktilsinamamid dengan menggunakan H-NMR menunjukkan kelompok alkena ditampilkan dalam posisi pada $\delta 6.46 \mathrm{ppm}(d, 1 \mathrm{H})$ dan pada $\delta 7.64 \mathrm{ppm}(d, 1 \mathrm{H})$. Cincin aromatik ditunjukkan pada posisi $\delta 7.48 \mathrm{ppm}(d, 2 \mathrm{H})$ dan $\delta 7.32 \mathrm{ppm}(d, 2 \mathrm{H})$. Kelompok alifatik ditunjukkan pada posisi $\delta 3.37 \mathrm{ppm}(q, 2 \mathrm{H}), \delta$ $1.24 \mathrm{ppm}(m, 10 \mathrm{H}), \delta 1.56 \mathrm{ppm}(m, 2 \mathrm{H})$ dan $0.85 \mathrm{ppm}(t, 3 \mathrm{H})$. Sedangkan untuk spektrum ${ }^{13} \mathrm{C}$ NMR menunjukkan bahwa pada $\delta 124.9$ ppm dan $135.8 \mathrm{ppm}$ adalah gugus olefin trans, $\delta 129.2, \delta 129.8, \delta 133.4$ dan $\delta 148.1 \mathrm{ppm}$ adalah gugus aromatik pada cincin benzen sinamamamid dan $\delta 164.9 \mathrm{ppm}$ adalah gugus karbonil pada senyawa oktilsinamamid. Kelompok alifatik ditunjukkan pada posisi $\delta$ $40.0 \mathrm{ppm}, \delta 31.9, \delta 22.7$ dan $\delta 14.2 \mathrm{ppm}$.

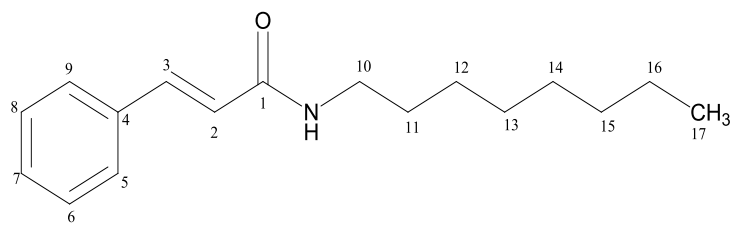

Gambar 4. Struktur senyawa oktil sinamamid

Tabel 2. Data ${ }^{1} \mathrm{H}$ NMR dan ${ }^{13} \mathrm{C}$ NMR untuk senyawa oktilsinamamid

\begin{tabular}{|c|c|c|}
\hline Posisi & $\delta \mathrm{C}(\mathrm{ppm})$ & $\delta \mathrm{H}$ (ppm) (multiplisitas,jumlah $\mathrm{H}, \mathrm{J}$ dalam Hz) \\
\hline 1 & 166.8 & - \\
\hline 2 & 120.2 & $6.42(d, 1 \mathrm{H}, J=15.55 \mathrm{~Hz})$ \\
\hline 3 & 141.7 & $7.63(d, 1 \mathrm{H}, J=15.55 \mathrm{~Hz})$ \\
\hline 4 & 135.2 & - \\
\hline 5 & 127.9 & $7.48(d, 1 \mathrm{H}, J=1.30 \mathrm{~Hz})$ \\
\hline 6 & 128.6 & $7.35(m, 1 \mathrm{H}, J=7.10 \mathrm{~Hz})$ \\
\hline 7 & 129.1 & $7.35(m, 1 \mathrm{H}, J=7.10 \mathrm{~Hz})$ \\
\hline 8 & 128.6 & $7.35(m, 1 \mathrm{H}, J=7.10 \mathrm{~Hz})$ \\
\hline 9 & 127.9 & $7.48(d, 1 \mathrm{H}, J=1.30 \mathrm{~Hz})$ \\
\hline$-\mathrm{NH}$ & - & $5.81(s, 1 \mathrm{H})$ \\
\hline 10 & 40.3 & $3.39(q, 2 \mathrm{H}, J=13.65 \mathrm{~Hz})$ \\
\hline 11 & 30.0 & $1.28(m, 2 \mathrm{H}, J=33.7 \mathrm{~Hz})$ \\
\hline 12 & 26.7 & $1.28(m, 2 \mathrm{H}, J=33.7 \mathrm{~Hz})$ \\
\hline 13 & 29.3 & $1.28(m, 2 \mathrm{H}, J=33.7 \mathrm{~Hz})$ \\
\hline 14 & 29.3 & $1.28(m, 2 \mathrm{H}, J=33.7 \mathrm{~Hz})$ \\
\hline 15 & 31.9 & $1.28(m, 2 \mathrm{H}, J=33.7 \mathrm{~Hz})$ \\
\hline 16 & 22.7 & $1.56(m, 2 \mathrm{H}, J=7.10 \mathrm{~Hz})$ \\
\hline 17 & 14.1 & $0.87(t, 3 \mathrm{H}, J=7.10 \mathrm{~Hz})$ \\
\hline
\end{tabular}




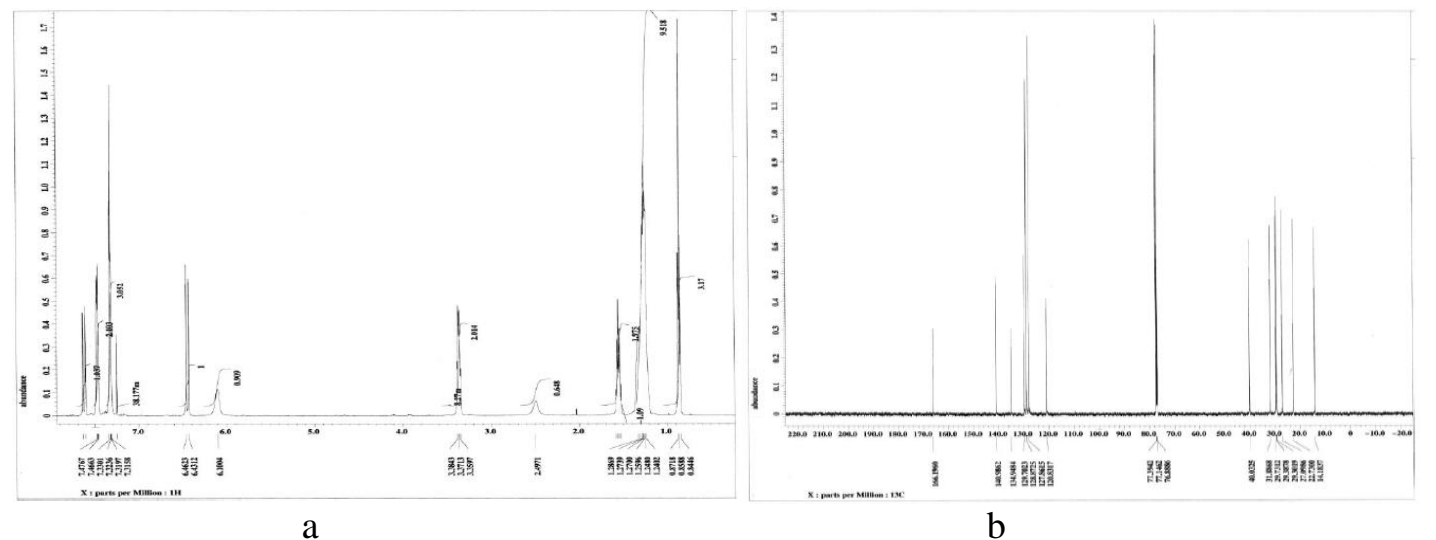

Gambar 5. Spektrum NMR (a) ${ }^{1} \mathrm{H}-\mathrm{NMR}$ dan (b) ${ }^{13} \mathrm{C}-\mathrm{NMR}$ senyawa oktilsinamamid

\section{Uji sitotoksisitas dengan Metode MTT}

Uji sitotoksisitas terhadap sel leukemia P388 dilakukan dengan metode MTT. Hasil pengujian senyawa $N$-oktilsinamamid tercantum dalam Tabel 3. Pengujian sitotoksisitas dengan metode MTT menunjukkan bahwa persentase inhibisi senyawa $N$-oktilsinamamid lebih aktif dibandingkan senyawa asalnya yaitu metil sinamat dan asam sinamat. Pengujian antikanker lebih lanjut perlu dilakukan terhadap senyawa $N$-oktilsinamamid terutama untuk uji in vivo agar diperoleh data yang lebih komprehensif.

Tabel 3. Hasil Pengujian sitotoksisitas terhadap sel leukemia P388

\begin{tabular}{llc}
\hline No. & Senyawa & IC $_{\mathbf{5 0}}(\boldsymbol{\mu g} \mathbf{g} \mathbf{m L})$ \\
\hline 1 & Metil Sinamat & 20.35 \\
2 & Asam Sinamat & 48.85 \\
3 & N-Oktilsinamamid & 6.71 \\
\hline
\end{tabular}

\section{SIMPULAN}

Hasil modifikasi struktur metil sinamat melalui reaksi amidasi asam sinamat dengan oktilamin sebagai senyawa pereaksi dan DCC (n,n'-dicyclohexylurea) serta DMAP (dicyclohexylcarbodiimide) sebagai katalisator menghasilkan $n$-oktil sinamamid $\left(\mathrm{C}_{17} \mathrm{H}_{25} \mathrm{NO}\right)$ dengan rendemen sebesar $53.65 \%$ dengan produk samping DCU (4dimethylaminopyridine) sebesar 30\%. Uji sitotoksisitas terhadap sel leukemia P388 menunjukkan bahwa senyawa $N$ - oktilsinamamid memiliki nilai $\mathrm{IC}_{50}=6.71$ $\mu \mathrm{g} / \mathrm{mL}$.

\section{UCAPAN TERIMA KASIH}

Penelitian ini terlaksana dengan biaya DIPA Pusat Penelitian Kimia LIPI tahun 2014.

\section{DAFTAR PUSTAKA}

Allen CL, Chhatwal AR, Williams JMJ. 2011. Direct amide formation from unactivated carboxylic acids and amines. $R$. Soc. Chem. 5: 666-668.

Bahrami K, Khodaei MM, Targhan H, Arabi MS. 2013. Preparation of esters and amides from carboxylic acids and $\mathrm{N}$-formylation of amines promoted by 1,3,5-triazo-2,4,6triphosphorine-2,2,4,4,6,6-hexachloride (TAPC). Tetrahedron Lett. 54(37): $5064-$ 5068.

Bhatia SP, Wellington GA, Cocchiara J, Lalko J, Letizia CS. 2007. Fragrance material review on methyl cinnamate. Food Chem. Toxicol. 45: S113-S119.

Cozzi P, Baraldi PG, Beria I, Caldarelli M, Geroni C, Pennella G,Romagnoli R. 2003. Cinnamoyl distamycin analogous derivatives, process for their preparation and their use as antitumor agents. U.S. Patent 6.596.845 B1,July 22.

De P, Baltas M, Bedos-Belval F. 2011. Cinnamic Acid Derivatives as Anticancer Agents-A Review. Curr. Med. Chem. 18: 1672-1703.

Dykes DJ, Waud WR. 1955. Murine L1210 and P388 Leukemias. 4: 23-41. 
Ernawati T, Fairusi D. 2013. Sintesis fenil sinamat dan 4-fenilkroman-2-on dan uji sitotoksisitas terhadap sel kanker serviks HeLa. J. Ilmu Kefarmasian Indones. 11(2): 202-210.

Ernawati T, Anita Y, Lotulung PD, Hanafi M. 2014. Synthesis of methyl 2-cinnamamido3-hydroxy propanoate having activity against p388 leukemia cells.J. Appl. Pharm. Sci. 4(03): 92-95.

HayakawaI, ShioyaR, AgatsumaT. 2004. Thienopyridine and benzofuran derivatives as potent anti-tumor agents possessing different structure - activity relationships. Bioorganic Med. Chem. Lett. 14(14): 34113414.
Humpries MJ, Matsumoto K, White SL, Olden K. 1986. Cancer Res. Cancer Res. 46: 52155222.

Lanigan RM, Starkov P, Sheppard TD. 2013. Direct synthesis of amides from carboxylic acids and amines using B $\left(\mathrm{OCH}_{2} \mathrm{CF}_{3}\right)_{3}$. J. Org. Chem. 78: 4512-4523.

Muchtaridi, Rambia I, Musfiroh I. 2008. Kadar Metil Sinamat dari Batang, Daun dan Rimpang Tumbuhan Laja Gowah (Alpinia Malaccensis (Burm f.)) dengan GC/MS. Fakultas Farmasi Universitas Padjajaran.

Wu B, Jin-Shui Z, Yi Z, Wei-Ming S, Qiang Z. 2008. Predictive value of mtt assay as an in vitro chemosensitivity testing for gastric cancer: one institution's experience. World Journal Gastroenterology. 14 (19): 30643068. 